\title{
Bacterial Blight of Shallot, Caused by Pseudomonas syringae pv. porri, a New Disease in Korea
}

\author{
Inn-Shik Myung*, Young-Kee Lee and Hongsik Shim \\ Crop Protection Division, National Academy of Agricultural Science, Rural Development Administration, Suwon 441- 707, Korea \\ (Received on August 25, 2011; Revised on December 17, 2011; Accepted on December 24, 2011)
}

Shallots (Allium cepa var. ascalonicum L.) affected by bacterial blight disease received for diagnosis in March 2007 (Fig. 1A). Grower has estimated and we have confirmed that as much as twothird of the plant was affected by the disease in fields in the Daejung District, Seokwipo of Jeju, Korea in April, 2007. The symptoms on leaves included yellowish and brownish leaf blight on leaf surface. Seriously infected plants shriveled and died in fields. Two isolates, BC2489 and BC2498 were recovered on trypticase soy agar (TSA) from symptomatic leaves of the plants. Pathogenicity was evaluated on seven-week-old shallots by spot and spray inoculation. Bacteria were grown on TSA for $48 \mathrm{~h}$ at $28^{\circ} \mathrm{C}$. Five $\mu$ l of bacterial suspension in sterile distilled water $\left(10^{5} \mathrm{cfu} / \mathrm{ml}\right)$ were spot-inoculated on pinpricked positions of five detached leaves for each isolate. The detached leaves were incubated in a plastic box with high humidity at $28^{\circ} \mathrm{C}$. Spot-inoculated surfaces turned white three days after inoculation followed by brownish discoloration. A bacterial suspension in sterile distilled water $\left(50 \mathrm{ml}\right.$ at $\left.10^{5} \mathrm{cfu} / \mathrm{ml}\right)$ was sprayed onto three plants for each isolate. Plants were maintained in a growth chamber at $26^{\circ} \mathrm{C}$ and $90 \%$ relative humidity. Isolates induced identical symptoms two weeks after spray inoculation as those originally observed on shallots in the fields (Fig. 1B). Bacteria were reisolated 3 weeks after inoculation from diseased lesions surface sterilized in $70 \%$ ethanol for $1 \mathrm{~min}$ and the identity of the reisolated bacteria confirmed by analyzing the sequences of $r p o D$ gene (Sawada et al., 1999). No symptoms were noted on detached leaves and intact plants inoculated with sterilized distilled water. The isolates were fluorescent on King's B agar and Gram-negative, aerobic rods with one to four polar flagella. The isolates belonged to Pseudomonas syringae (LOPAT) group Ia $(+,-,-,-,+)$ (Lelliott et al., 1966). The gyrB and $r p o D$ regions (Sawada et al., 1999), and $r p o B$ region (Tayeb et al., 2005) of the isolates were partially sequenced to aid in identification of the two original field isolates using reported primers (Sawada et al., 1999; Tayeb et al., 2005). The rpoB region $(1,119 \mathrm{bp})$ of the isolates shared $100 \%$ sequence identity with $P . s$. pv. porri CFBP $1908^{\mathrm{PT}}$. Phylogenetic analysis based on partial sequences of the $g y r B$ (686 bp) and $r p o D$ (615 bp) loci of Psudomonas spp. available in the Genbank (Sawada et al., 1999; Tayeb et al., 2005), the reference strain of $P$. syringae pv. porri CFBP 1908PT, and the isolates reported in this study was conducted using Jukes-Cantor model in MEGA Version 4.1 (Tamura et al., 2007). The isolates and the reference strain of $P$. syringae pv. porri CFBP $1908^{\mathrm{PT}}$ were clustered in one group (Fig. 2A and 2B). On the basis of

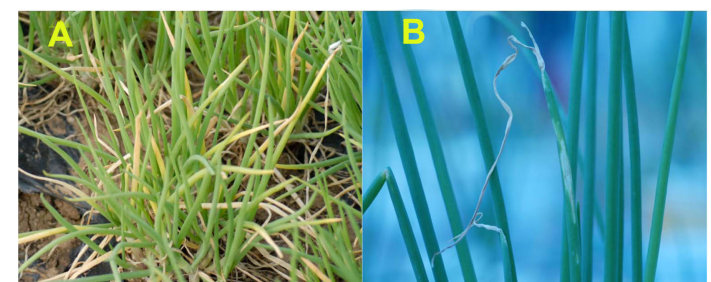

Fig. 1. Bacterial blight symptoms on shallot in field (A). Symptoms on shallot induced two weeks after spray inoculation with a cell suspension $\left(10^{5}\right.$ $\mathrm{cfu} / \mathrm{ml}$ ) of Pseudomonas syringe pv. porri strain BC2486 from shallot (B).
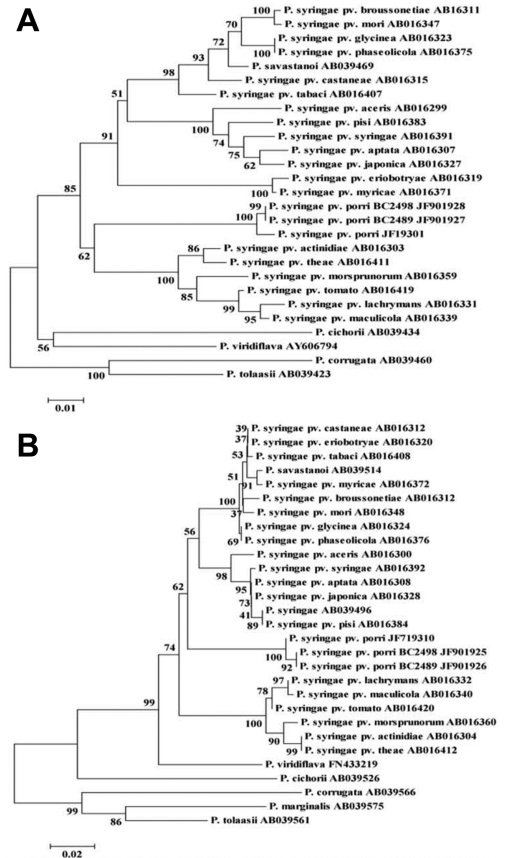

Fig. 2. Phylogenetic trees derived from the neighbor joining model in MEGA software (ver. 4.1) based on partial sequences of gyr $B(\mathrm{~A})$ and $r p o D(\mathrm{~B})$ genes of Pseudomonas syringae pv. porri strains BC2486 and BC2498 from shallot. Number represents bootstrap values based on 500 samples.

phenotypic, pathological characteristics and the sequences, the two isolates were identified as $P$. syringae pv. porri. To our knowledge, this is the first report of bacterial blight of shallot caused by $P$. syringae pv. porri in Korea. The disease is expected to have a significant economic impact on shallot culture in the fields of Jeju Province in Korea.

\section{Acknowledgment}

This study was supported by Agenda 5-12-30 of Rural Development Administration in Korea.

\section{References}

Ait Tayeb, L., Ageron, E., Grimont, F. and Grimont, P. 2005. Molecular phylogeny of the genus Pseudomonas based on rpoB sequences and application for the identification of isolates. Res. Microbiol. 156:763-773.

Lelliott, R. A., Billing, E. and Hayward, A. C. 1966. A determinative scheme for the fluorescent plant pathogenic pseudomonads. J. Appl. Bacteriol. 29:470-489.

Sawada, H., Suzuki, F., Matsuda, I. and Saitou, N. 1999. Phylogenetic analysis of Pseudomonas syringae pathovars suggests the horizontal gene transfer of $\operatorname{argK}$ and the evolutionary stability of $h r p$ gene cluster. J. Mol. Evol. 49:627-644.

Tamura, K., Dudley, J., Nei, M. and Kumar, S. 2007. MEGA4 Molecular Evolutionary Genetics Analysis (MEGA) software version 4.0. Mol. Biol. Evol. 24:1596-1599.

*Corresponding author (ismyung@rda.go.kr) 